\title{
Issues and Concerns of School Teachers around the World: A Review
}

\author{
Rayeesa Akhter ${ }^{1}$ and Sushila Mahor ${ }^{2}$ \\ ${ }^{1}$ Department of Sociology, Jiwaji University, Gwalior, Madhya Pradesh, India \\ ${ }^{2}$ V.R.G Girls PG College, Morar, Gwalior, Madhya Pradesh, India \\ E-Mail: rayeesaakhter@gmail.com
}

\begin{abstract}
Education is essential for everyone that helps people earn respect and recognition. The profession of teaching is one of the most valuable and important profession of all the professions as teacher is regarded as builder of nation. Different problems of teachers have been identified across the globe by various researchers. Although, there are some problems that are unique to the world teachers but some regional problems were also highlighted. This paper has highlighted the issues, concerns and problems of teachers all over the world.
\end{abstract}

Keywords: Teachers, Problems, Issues, Concerns, Intervention

\section{INTRODUCTION}

Education is essential for everyone. It is the level of education that helps people earn respect and recognition. In general opinion, it is an indispensable part of life, both personally and socially. It is a life-long process for each person which needs to be reinforced throughout life. Knowledge is power, and education imparts knowledge. Teachers are an extremely important facet of any society for a multiple of reasons. Teachers pass on knowledge and values to children, prepare them for future education and for working life and are the main contributors to good education. Teachers are one of the main pillars of a sound and progressive society. They bear the responsibility of teaching, and apart from parents, are the main source of knowledge and values for children (Solomon, 2007). A critical examination of the present day teachers revealed that plays comparatively a minor role in the present decorative educational standards of the country. The position of the teachers, both is private and government sector is so insignificant that they are unable to meet the challenges of modern education. They have to face hurdles and concerns of society that is causing great impact on the overall development of society. In order to address and highlight the concerns and problem that are being faced by the teaching community the following study has been undertaken (Rao, Khadar, 2015).

Merton explained "problem is deviation ideals, originated on common basis and inter related with other problem, effects all members and sections and needs collective approach of solution. In this study the problems of school teachers mean the position administratively as well as socially held by teachers through which they are performing their jobs and responsibilities and facing problems in their performance"(Merton,1938).

Every profession has advantages and disadvantages, similarly school teachers face a number of problems. The problems of teachers vary in government and private schools and are significantly different in private educational institutions. The problems are professional and academic in nature, personal and interpersonal. They may be administration and related to management and the general motivation and overall job satisfaction of the teachers. In the present study, we collected data from male and female teachers in order to find the deviations of problems faced by this community while disseminating the knowledge to pupils under various circumstances and on different salary package.

\section{ISSUES AND CONCERNS OF SCHOOL TEACHERS}

The survey of related studies indicates locating, evaluating and studying reports of relevant researches, study of published articles going through related portions of manuals and research abstracts, study of pertinent pages out of comprehensive books on the subject and going through related manuscripts if any. Research takes the advantage of the knowledge which has accumulated in the past as a result of constant endeavor. It can never be undertaken in isolation of the work that has already been done on the problems which are directly or indirectly related to study proposed by a researcher. The review literature to the current study was not properly developed to the problems of the area. However, the following is the collection of review from different related fields and can be correlated with the current study.

Ahmed, Raheem and Jamal (2003) studied the job satisfaction of 236 teachers in senior secondary schools. Female teachers enjoyed greater satisfaction than their male counterparts did. Married teachers showed more job satisfaction than unmarried teachers did. Teachers who were teaching in government schools showed greater job satisfaction than teachers teaching in private schools. There was no significant change in the job satisfaction due to change in the level of independent variables like sex, marital status and types of schools. 
Tooley, et al., (2005) argued that the census and survey of schools in selected poor areas of Lagos State Nigeria explored the nature and extent of private education and compared inputs to public and private schooling. About $71 \%$ were found to be private with more unregistered private than government and registered private schools. It was estimated that $33 \%$ of school children were enrolled in private unregistered schools and $75 \%$ in private schools in general. Teaching activity was found to be considerably higher in private than government schools, and teacher absenteeism was lowest in private schools. Most school inputs showed either comparable levels of provision in government and private schools, or superiority in private schools. Dhingra (2006) studied the effect of organization climate on job satisfaction of secondary school teacher from different government and private schools of Patiala district Punjab. It was found that there is no significant difference in job satisfaction of government and private secondary school teachers. Nath (2008) investigated the problems of female school teachers in four districts of the state of Kerala. Methodology of the study was followed the descriptive research. The sample of the study was 400 female school teachers and purposive Random sampling was used to select the sample. The primary data was collected with the alleviate their problems in a time bound manner. Thangarajathi and Tamilselvi (2009) concluded their study education is an important social activity, closely bound with intellectual, economic, cultural and help of questionnaire and interview, focus group interviews, observation etc. And it has been found that the problems of employed women will vary with the nature of job in which she was working and family set up. With proper practice of yoga school teachers can create the right kind of chemistry they are naturally peaceful joyous and loving within themselves inner science of yoga help teachers liberate from their problems and sufferings both physically and psychologically.

Chan, Chen and Chong (2010) investigated the work stress of teachers from primary and secondary school Hong Kong. Self- administrated questionnaire was used to collect the data. Random sampling method was used for this study. The collected data was then analyzed by using SPSS. The result of the study was the majority of the respondents the source of work stress reported by the teachers were heavy workload and time pressure comparing with one year and five years ago, the responding teachers an increase of perceived stress level. The most frequently reported source of life stress was unstable economy, other sources include financial stress, family problems children education and children stress. Salem al-Amarat (2011) identified the classroom problems that faced school teachers in Tafila province in Jordan. The sample 240 male and female teachers was selected simple randomly. Questionnaire was used to collect the primary data. Descriptive statistics was applied to test the data. From the analysis it was found that the level of the classroom problems of the education was medium. From the teacher's point of view there was no statistically significant difference, in the academic problems domain, while there was a statistically significant difference, in the behavioral problems due to the interaction variables gender, school level and experience.

Omoteso and Semudara (2011) investigated the nature of classroom misbehaviors among secondary school students in Ondo State Nigeria. The study adopted descriptive survey design. The sample of 420 teachers and 180 school administrators selected randomly from 10 secondary schools selected by stratified sampling technique. Two instruments namely Questionnaire on Management of Classroom Misbehavior (QMCM) and Teachers' Effectiveness Scale (TES).The study concluded that the secondary school students studied were involved in classroom misbehaviors' such as fighting, talking while the teachers were teaching, and eating during lessons. Managing the classroom misbehaviors' would depend on how effective the teachers are, because this study found a significant positive relationship between teachers' effectiveness and management of classroom misbehavior. Nadeem, Rana, and et al., (2011) studied the factors affecting the performance of female teachers in urban and rural areas of Bahawalpur (Southern Punjab) Pakistan. The study was descriptive in nature. Two questionnaires were used to collect the data one for the teachers and one for students were developed on Likert type scale. Data was analyzed by using t-test and ANOVA in SPSS software. The results have been found that the findings open a number of options for teachers and planners to manipulate the relationship for promoting the performance of female teachers. Poor socio-economic status of teachers affects the teacher's performance. Poor socio-economic condition of the area where school is situated decreases the teacher's motivation but society gives more respect to female teachers as compare to male teachers. Undue political interference also affects the teacher's performance. A positive relationship was found between most of the factors and the performance of female teachers.

Chohan, Shafiq and Naseem (2011) examined job satisfaction among female primary school teachers from public and private sectors in District Lahore. Self-designed questionnaire was used for data collection from the sample size of 400 primary school teachers. The collected data was then analyzed by using SPSS and applied different techniques like Chi-square and Z-Test. This study showed that the satisfaction level of government teachers is higher than the private sector as far as salary level is concerned and it is also observed that government teachers feel their jobs are secure as compared to private school teachers. However, there are some important problems faced by female teachers like public transport, encashment of leave at the end of year and live long distance from school.

Roshan lal and Shergill (2012) investigated the job satisfaction among male and female teachers of degree colleges of Punjab and Haryana state. The study was descriptive in nature. The structured questionnaire was used to collect the primary data the sample size was 200 teachers 
both male and female. The study reveals that teachers are very satisfied with their jobs. The male groups of teachers have the mean value 74.35 , thus it corresponds to the extremely satisfied category as per the manual and the female teachers also fall in the extremely satisfied category with the mean value of 74.55. Therefore, it was evident that female degree college teachers have more favorable attitude towards education as compared to their male counterparts. The difference between the mean is non-significant with tvalue 0.104 . It was inferred that both male and female teachers do not significantly regard the attitude towards education. Suleman, Hussain and et al., (2012) investigated to identify the problems faced by male and female secondary school teachers in Kohat Division Khyber Pakhtunkhwa Pakistan. The results have been found that there are various problems which negatively affect the performance of secondary school teachers unattractive pay package, lack of basic facilities, overcrowded classes, long distance to school, autocratic environment inside school etc. further findings was recommended that teachers should be given special pay package and educational facilities should be provided to them. Sindhi (2012) investigated the plight of non-government teachers in India. The study was descriptive in nature and population of this study comprise of all the private schools of Baroda city. 10 private schools selected purposively sample of the study. Data was collected by using questionnaire and interview schedule. Content analysis technique was used to summarize the results. The study also found that private teachers especially those who work in small privately owned schools are vulnerable to lack of job security and hostile and stringent work environment at work place. Such an oppressive has lead to the job dissatisfaction, depression and lack of interest in work and sense of alienation among most of the teachers working in small private schools. Besides exploitation, over work, minimum wages, discrimination in salaries and lack of mental satisfaction at work place are some pressing problems of such school teachers though such problems vary from institution to institution and cannot be generalized for all the privately owned educational institutions at any place of the country.

Khan and Iqbal (2012) aimed to investigate the most serious problems faced by the teachers in overcrowded classes at the secondary level in district Peshawar, Province of Khyber Pakhtunkhwa, Pakistan. The study was descriptive in nature. The close ended questionnaire was used to collect the data from the sample size of 40 teachers. Qualitative as well as quantitative method of data collection was used. Random sampling method was used for this study. The outcome of the study indicated that effective teaching was not possible in overcrowded classes and majority of the teachers were facing instructional, discipline, physical and evaluation problems. In order to solve these problems some implementable measures were made which suggested that government should make strict rules and policies regarding optimum students in classrooms and provide sufficient budget to education department for providing better facilities in schools. Sultan, Bano and et al., (2012) identified the nature and impact of teacher stress in the private schools of Gilgit-Baltistan of Pakistan. Qualitative research methodology was used for data collection. Four semi-structured interviews of the research participants were used in this research. The data categorically delineated that the stress factors left various marks on teachers influencing (often negatively) their morale and motivation and therefore, impacted their sense of professionalism and classroom performance.

Wang and Zhang (2012) investigated the anxiety has become one of the major psychological problems which harass people in modern times this problem is particularly obvious with primary and middle school teachers. The selfcompiled Teachers State Anxiety Questionnaire (TSAQ) was used to collect the data and investigate the effective of 1930 subjects in seven regions of China. The results show that the sense of anxiety for satisfaction and control is higher in male teachers and conflict is severe in the key middle school. Ahmad, Rehman and et al., (2013) analyzed the problems of government secondary school system in Pakistan. The findings of study presented in a descriptive form. The study existing literature was deeply and critically reviewed. Analysis of literature results showed that the system is affected due to the following main reasons. There are different problems at various levels. The system is financed poorly. There is a lack of motivation among teachers. In some places the teachers are transferred from one place to another on the basis of favoritism and nepotism. Study further found that the system is affected due to political interference in the process of selection as a result, under-qualified teachers are appointed who cannot effectively manage the process of teaching and learning in schools effectively which is reflect in poor performances of students and dissatisfaction among parents regarding the performance of government schools.

Kaur (2013) examined the relationship between spiritual intelligence and job satisfaction of secondary school teachers of Amritsar district. Quantitative approach is applied in this study. 100 respondents based on nonprobability sampling technique have been taken for the study. This study used a descriptive correlation design to examine the relationship between spiritual intelligence and job satisfaction and questionnaire comprising self-rated five-point scale was used to collect the data. The findings of the study revealed a significant positive relationship between teachers' spiritual intelligence and their job satisfaction. A significant difference is found between spiritual intelligence of government and private secondary school teachers. But insignificant difference is found between job satisfaction of government and private secondary school teachers. The study also indicated that spiritual intelligence and job satisfaction are not influenced by gender. Maulana Usop and Askandar and et al., (2013) aimed to study the relation of work performance and job satisfaction among teachers of Division of Cotabato City. The study was based on primary data collected through survey questionnaire. The sample of the study was 200 
elementary teachers from twelve selected public schools. The study used them descriptive correlation design. Analysis was used to test the descriptive statistics such as group frequency distribution, percentile, mean and standard deviation. This implies that a teacher's satisfied with their job is also a productive one. Furthermore, if the teachers contented with their job, they will develop and maintain high level of performance. Teaching learning process make more efficient and effective that could produce high competitive learners.

Moorthy (2013) investigated the Job Satisfaction of Female School Teachers in Theni District. The study was empirical research based on the survey method. The study is based on both primary and secondary data. The primary data was collected with the help of interview schedule. The female school teachers are somewhat satisfied. The study result helps the management to take necessary step to maintain conducive work environment. The work environment influences the job satisfaction. The majority of the female salary is secondary income for their family. So the management may encourage them to save money in various investments, this investment helps to their family and our nation. Galgotra (2013) studied the mental health of government and private teachers and its relation to sex and job satisfaction of Jammu. The sample of 250 teachers was selected from different High schools of Jammu district. Government and private school teachers have been taken as the respondents of the study. Three-way ANOVA (Factorial experiment) was employed to test the data. Mental health inventory and job satisfaction inventory was used. It was found that government school teachers possess good mental health in comparison to private school teachers. Sex has no effect on the mental health of teachers. Further findings show that job satisfaction has an effect on the mental health of the teachers.

Akhtar (2013) studied the different reasons of absenteeism between private and public school teachers at secondary level in district Bahawalnagar, Punjab, Pakistan. Sample of 160 participants was selected 80 participants were from government schools and 80 were from private schools. A questionnaire was used as a research tool for the analysis of data percentages were found out. The result of the study revealed that the teachers of government schools have better salary than the teachers of private schools. Preetika and Priti (2013) aimed to explore that kind of challenges a principal faces and how she goes about meeting them. The sample comprised five schools out of which two were government, two were private and one was aided school. The total numbers of principals interviewed were five. Interview schedule was formulated and used for interviewing principals. To understand the challenges of leadership in different schools, three types of schools. Various issues like administration, qualities of a principal, kind of challenges a principal face, strategies a principal use to resolve problems, the balancing act were investigated. Shah, Khan and IrfanUllah (2014) studied the problems faced female teachers at primary level in Khyber Pakhtunkhwa Pakistan. The study concluded that female teachers are overburdened with extra classes due to shortage of female staff in the girls' schools. Be short of resources in girl's schools render the female teachers helpless while they need different aids for schooling and learning. There are no training facilities available to professionally update the female teachers to improve their teaching skills.

Ravi (2014) investigated the problems faced by the teachers in teaching English in rural secondary schools of Krishna district in Andhra Pradesh. The study was descriptive research. The sample of the study consisted of 30 English teachers. Questionnaire was used to collect the primary data. The result of the study has been found that many problems faced by the teachers in teaching English such as problems related to school facilities, problems related to availability of instructional resources to teach English and problems related to the background of the teachers. Chaudhari (2014) examined the teaching related problems faced by the Secondary school teachers of kheda district Gujarat. The sample100 Secondary school teachers were randomly selected from rural and urban areas. The data was collected through questionnaire and survey method. Statistical techniques were used to analyze the data. In this research it was examined that it is necessary to understand conditions of our teachers who are the soul of our education system. Today, teachers are facing many problems among which the most important is teaching related problem. In this research the researcher has made a humble attempt to suggest remedies by finding out teaching related problems of the Secondary School teacher.

Hasan (2014) made a comparative analysis level of occupational stress of primary government and private school teachers of Uttrakhand. The study was exploratory in nature. 100 respondents based on stratified random sampling technique have been taken for the study. The study was based on primary data. Questionnaire was used to collect the data on the basis of Likert type scale. Different statistical techniques like mean, mean deviation and t-test were compare groups to test the data.

The findings revealed that in general, the primary school teachers have found to be highly stressed. Moreover, the private primary school teachers have also found to be highly stressed in comparison to their government primary school teacher counterparts. Shabbir, Wei and et al., (2014) made a comprehensive study to compare the performance, achievements and effectiveness of government versus private primary schools in rural areas of Azad Jammu \& Kashmir. After collecting data, the independent sample ttest was applied to evaluate the scores.

From the analysis it was found that Private schools perform better than public schools in maximum measures of performance except a few which have been taken in this study, but both public and private schools face a number of challenges. Both sectors still deprive of quality of human and material resources for the provision of standard education. 
Mohamed Al-Faki and Khamis (2014) investigated the difficulties that teachers experience when they use interactive whiteboard in English language classes include elementary, intermediate, and secondary schools in Jeddah, KSA. The study was descriptive research method. Primary data was collected through questionnaire, twenty-five statements besides the researcher's observation and his own experiences in more than 300 schools. Not all schools in Jeddah are equipped with Interactive Whiteboards, data projectors or computers. Microsoft Office Program Excel was used for analyzing the data. The collected data was transformed into figures and tables to facilitate interpretation. The researcher conducted a pilot survey and used statistical techniques through validity and reliability test were verified. The findings of the study have revealed that there are many challenges that teachers face when using the interactive whiteboard. Those challenges interact together to hinder IWB integration into teaching and learning. Kosgei (2015) investigated the challenges facing staff development and training needs of teachers of English in secondary schools in Kenya with reference to Kericho County. The results of the study were found that the constraints to the teacher participation in staff development programmes arose because teachers did not take personal initiative to overcome the constraints, schools did not look for cost effective ways of organizing staff development programs while head teachers concealed existence of LT and $\mathrm{T}$ funds from their teachers. Teachers must therefore appreciate the importance of taking part in the staff development and training for their personal and professional growth.

Chamundeshwari and Bakiaraj (2015) investigated the attitude towards and problems faced by teachers in the implementation of ALM (active learning methodology) in schools at the upper primary level in Dharmapuri district. The results of the statistical analyses show a significant negative correlation between attitude towards implementation of ALM and problems faced by teachers in implementation of ALM. No significant difference is observed between the male and female teachers in government and government-aided schools at the upper primary level in Dharmapuri District pertaining to attitude towards and problems faced implementation of ALM. Kumar and Singh (2015) studied the level of adjustment of secondary school teachers in relation to organizational climate. Different statistical tests like standard deviation and t-test were employed to test the data. From the results of the study, that there is a negative and insignificant relationship between adjustment and organizational climate of secondary school teachers. There is no significance difference exist between the adjustment as well as organizational climate of secondary school teachers with respect to gender and areas.

Mangad and Nath (2015) investigated the problems of higher secondary school principals in Kerala. The study revealed that 94.83 percent higher secondary principals are facing practical difficulties to do office work along with classroom teaching. This unexpected frequent transfer causes a lot of dislocation and class management problems. Rashid and Maharashi (2015) studied the problems of female school teachers in district Kulgam of Jammu and Kashmir. The study was descriptive research. Purposive random sampling technique was adopted to collect information from the respondents. The study identified by using tools such a questionnaire and interview schedule from the sample size 100 school teachers. The purpose of this study was to find out the problems of employed female school teachers and found that non-cooperation of family members is identified as the major problems of female teachers, also the workload of most of the female teachers has an average of 20 periods per week and also it has found that they are facing many personal problems.

Jan and Khan (2015) investigated the Morale of Science and Arts Higher Secondary School Teachers of Kashmir Division. The data was collected by Morale questionnaire. T- test was used for the analysis of data. The results have been found that their study science higher secondary school teachers and arts higher secondary school teachers are having same morale on composite score. Kavitha and Venkateswaran (2015) investigated the teaching attitude and job satisfaction of secondary school teacher's in Salem district. Only satisfied and well-adjusted teacher can think of the well-being of the pupils. In the light of this background, the aim of this study is to analyze the Teaching Attitude and Job Satisfaction among the Secondary School Teachers.

Shabbir and Song Wei (2015) studied to analyze the job satisfaction among public and private school teachers in Pakistan Administrative Kashmir. The sample of 300 teachers consisting 150 public school teachers and 150 private school teachers were taken randomly selected from three divisions of J\&K. Survey technique was applied based on questionnaire was used to collect the data. These findings provide valuable insights about the subject matter as it is essential to provide all benefits and working environment besides appropriate social and emotional factors in the education institutions. It is essential for policy makers to identify the fact that educational quality is largely related with regard to teacher job satisfaction. Chandra Rao (2015) studied to analyze the job satisfaction among secondary school teachers Vijayawada city. The study revealed that there is no significant difference was found between the job satisfaction of male and female teachers of secondary schools. Secondary school senior teachers have more job satisfaction than junior teachers. Government secondary school teachers are satisfied with regard to their job as compared to private secondary school teachers.

Makunja (2016) investigated the challenges facing teachers in implementing competence based curriculum in secondary schools in Tanzania. The results of the study were found that teachers faced a variety of challenges which impeded the effective implementation of competence based curriculum in teaching and learning. Further, it has found from the study that teachers should be given opportunities 
for their participation in formulation and review of curriculum. Also the Ministry of Education and Vocational Training should devise ways of providing quality and relevant teaching and learning resources that are consistent with the competence based curriculum. Jadal (2016) studied the problems of female school teachers working schools and their job satisfaction in Solapur district of Maharashtra. The study was based on both primary and secondary data. Primary data collected through interview schedule. 164 women teachers were taken as the respondents of the study. The result of the study showed that analyze the attitude of women teachers towards the various service provided by the schools and also to ascertain their attitude towards job satisfaction. Teaching is a profession that needs special training intended to build up knowledge competencies develop skills and favorable attitude towards learners. Subramonian and Sanbahavalli (2016) investigated the relationship between job satisfaction and the teaching competence of higher secondary school teachers. Most of the teachers can spend more time developing deep insight into subjects. They showed personal interest and involvement in teaching competency. In this study $84 \%$ of the result proved that there is no significant difference between Teaching Competency relations to Job Satisfaction.

\section{CONCLUSION}

There are various problems and concerns that have been identified. However, these problems lead to inconsistency and frustration, making teachers' lives more difficult. Adequate attention isn't always made available, and many teachers are left to fend for themselves to figure out how to deal with these issues. On the other side, some schools like private schools are resistant to change, and teachers who are educated about learning trends may not receive funding or support to adopt them. This can lead to a lack of job satisfaction and teacher turnover, and it can hold students back from delving into a new way to learn that may actually help them achieve more.

\section{REFERENCES}

[1] Solomon, V. (2007). Change management on behavior of teaching fraternity at college level, International journal of management, $8(2)$, 81-88.

[2] Rao, D. B. \& Khadar, S. A. (2015). Problems of private school teachers (1st edition), New Delhi-110002, Discovery publishing house pvt. Ltd.

[3] Merton, R. K. (1938). Social structure and Anomie. Bloomington, Indiana.

[4] Ahmad, N., Raheem, A. \& et al.,, (2003). Job satisfaction among school teachers, The Educational Review, 7(2).

[5] Tooley, J., Dixon, P. \& et al.,, (2005). Private and public schooling in low income areas of lagos state Nigeria: A census and comparative survey, International Journal of Educational Research, 43, 125-146.

[6] Dhingra, R. K. \& Kaur. R. (2006). Effect of organizational climate on job satisfaction of secondary school teacher. M.Ed. Thesis, Punjabi University Patiala.

[7] Nath, B. K. (2008). Problems of female school teachers in Kerala, Research Study, July 2008.

[8] Thangarajathi, S. \& Tamilselvi, B. (2009). Natural healing of problems of school teachers with the inner science-yoga, The Journal of Yoga, 8(1).
[9] Chan, H. S. Chen, K. \& et al.,, (2010). Work Stress of Teachers from primary and secondary schools in Hong Kong, proceedings of the international multi conference of engineers and computer scientists, iii.

[10] Salem al-amarat, M. (2011). The classroom problems faced teachers at the public schools in tafila province and proposed solutions, international journal education science, 3(1), 37-48.

[11] Omoteso, B. A. \& Semudara, A. (2011). The relationship between teacher's effectiveness and management of classroom misbehaviors in secondary schools, Scientific Research, 2(9), 902-908.

[12] Nadeem, M., Rana, M.S. \& et al., (2011). Teachers competencies and factors affecting the performance of female teachers in Bahawalpur southern Punjab Pakistan, international journal of business and social science, 2(19), 217-222.

[13] Chohan, A. A., Shafiq, M.M. \& et al., (2011). Job satisfaction among primary female school teachers: a case study of Lahore district, electronic journal.

[14] Roshan lal \& Shergill, S.S. (2012). A comparative study of job satisfaction and attitude towards education among male and female teachers of degree colleges, International Journal of Marketing Financial Services and Management Research, 1(1), 57-65.

[15] Suleman, Q. Hussain, I. \& et al., (2012). Identification of the problems faced by secondary school teachers in kohat division Pakistan, International Journal of Learning \& Development, 2(5), 324-340.

[16] Sindhi, S. (2012). The plight of non-government teachers of India, International Journal of Humanities and Social Science Invention, l(1), 45-49.

[17] Khan, P. \& Iqbal, M. (2012). Overcrowded class room: A serious problem for teachers, Elixir International Journal, 49, 10162- 10165.

[18] Sultana, B., Bano, Y. \& et al., (2012). The nature and impact of teacher stress in the private schools of Gilgit Baltistan Pakistan, International Journal of Academic Research in Progressive Education and Development, 1(2).

[19] Wang, L. \& Zhang, D. (2012). Characteristics of anxiety among primary and middle school teachers: A content based approach to state anxiety, 4(1), 26-31.

[20] Ahmad, I., Rehman, S. \& et al., (2013). Problems of government secondary school system in Pakistan: critical analysis of literature \& finding a way forward, International Journal of Academic Research in Business and Social Sciences, 3(2), 85- 96.

[21] Kaur, M. (2013). Spiritual Intelligence of Secondary School Teachers in Relation to their Job Satisfaction, International Journal of Educational Research and Technology, 4(3), 105-109.

[22] Maulana-usop, A., Ask \& ar, K. Z. \& et al., (2013). Work performance and job satisfaction among teachers, International Journal of Humanities and Social Science, 3(5), 245-252.

[23] Moorthy, D. (2013). A study on the job satisfaction of female school teachers in Theni district, Indian journal of Research, 2(8), 39-41.

[24] Galgotra, M. (2013). Mental health of high school teachers in relation to their sex and job satisfaction, International Journal of Humanities and Social Science Invention, 2(1), 20-23.

[25] Akhtar, M. (2013). A comparative study of government and private school teachers to explore the causes of absenteeism at secondary level in district Bahawalnagar Punjab Pakistan, Journal of Education and Vocational Research, 4(8), 225-229.

[26] Preetika, B., \& Priti, J. (2013). A descriptive study on the challenges faced by school principals, International Research Journal of Social Sciences, 2(5), 39-40.

[27] Shah, S. F., Khan, D. \& et al., (2014). Problems faced by female teachers at primary level in Khyber Pakhtunkhwa Pakistan, International Online Journal of Primary Education, 3(2), 24-32.

[28] Ravi, V. (2014). Identification of the problems faced by teachers in teaching English in rural secondary schools of Krishna district in Andhra Pradesh, Reviews of Progress, 1(38).

[29] Chaudhari, D. K. (2014). A study of teaching related problems experienced by secondary school teachers of kheda district, International Journal for Research in Education, 3(7).

[30] Hassan, A. (2014). A study of occupational stress of primary school teachers, Educationia Confab, 3(4), 11-19.

[31] Shabbir, M., Wei, S. \& et al., (2014). A comparative study of public versus private primary school teachers, an evidence of azad Kashmir Pakistan, Journal of Education and Practice, 5(9), 154-168. 
[32] Alfaki, I. M. \& Khamis, A. H. (2014). Difficulties facing teachers in using interactive whiteboard in their classes, American International Journal of Social Sciences, 3(2), 136-158.

[33] Kosgei, K. K. (2015). Challenges facing staff development and training: a survey of secondary schools in kericho county, International Journal of Humanities and Social Science Invention, 4(2), 34-47.

[34] Chamundeshwari, S. \& Bakiaraj, S. (2015). Attitude towards \& problems faced by teachers in the implementation of active learning methodology in schools at the upper primary level in Dharmapuri district, Global Journal of Inter Displinary Social Sciences, 4(3), 5761.

[35] Kumar, A. \& Singh, V. (2015). Adjustment of secondary school teachers in relation to organizational climate, Indian Journal of Applied Research, 5(9), 350-352.

[36] Mangad, A. \& Nath, B. K. (2015). Problems of higher secondary school principals in karela- dual role of classroom teaching and school administration, International Journal of Applied Research, 1(2), 1028-1031.

[37] Rashid, R. \& Maharashi, S. K. (2015). Problems of female teachers in district kulgam (J\&K), Journal of Education and Practice, 6(11).

[38] Jan, N. \& Khan, M. A. (2015). Morale of teachers working in various higher secondary schools of Kashmir division - A comparative study of science \& arts teachers, Global Advanced Research Journal of Educational Research, 4(9),170-175.

[39] Kavitha, S. \& Venkateswaran, R. (2015). Teaching attitude and job satisfaction of secondary school teachers, Shanlax International Journal of Education, 3(4), 1-6.

[40] Shabbir, M. \& Wei, S. (2015). Job satisfaction variance among public and private school teachers, case of Pakistan administration Kashmir, Mediterranean Journal of Social Sciences, 6(4), 574- 58.

[41] Chandra Rao, V. R. (2015). Job satisfaction among secondary school teachers, International Journal of Academic Research, 2(5), 92-96.

[42] Makunja, G. (2016). Challenges facing teachers in implementing competence based curriculum in tanzania: The case of community secondary schools in morogoro municipality, International Journal of Education and Social Science, 3(5), 30-37.

[43] Jadal, M. M. (2016). Problems of female teachers working in primary schools and their job satisfaction with reference to teachers working in Solapur district, Indian Streams Research Journal, 6(1), 1-8.

[44] Subramonian, G \& Sanbahavalli, A. (2016). A study on relationship between teaching competence and job satisfaction among higher secondary school teachers of coimbatore city, International Journal of Business and Administration Research Review, 1(2), 89-96. 